\title{
Perspektywa w ujęciu kognitywnym jako narzędzie analizy tekstu literackiego. Cwiczenia stylistyczne Raymonda Queneau
}

\section{Wstęp}

Słowo perspektywa oraz jego synonimy są często używane w odniesieniu do operacji mentalnych, o czym świadczą takie wyrażenia, jak spojrzeć na coś z innej perspektywy; z mojego punktu widzenia; spójrzmy na to pod innym kątem; z jednej strony / $z$ drugiej strony, opierające się na rozumieniu perspektywy jako „odległości w czasie umożliwiającej właściwą ocenę zdarzeń” (Słownik języka polskiego 2002: 649) lub ,punktu widzenia, z jakiego coś jest przedstawiane lub oceniane" (Słownik języka polskiego). Drugie z podanych słownikowych wyjaśnień nawiązuje do metafory WIEDZIEĆ TO WIDZIEĆ, będącej z kolei częścią szerszego pojęcia znanego jako ucieleśniony umysł (THE MIND IS A BODY; zob. Tabakowska 2001: 693). Ponieważ powyższe metafory pojęciowe są najprawdopodobniej uniwersalne, podobne wyrażenia można znaleźć w różnych językach, np. w angielskim i hiszpańskim, zob. point of view; view sth from [this ot that] angle; have a certain viewpoint; de su perspectiva; cambiar su perspectiva I punto de vista.

Etymologicznie, leksem łaciński perspectivus pochodzi od czasownika perspicere, oznaczającego badać, oglądać, przeglądać. Pierwotnie słowo to było związane z optyką, a jego pierwsze użycie datuje się na ok. 1397 r. Pod wpływem włoskiego prospettiva zostało zaadaptowane do dziedzin sztuki i architektury pod koniec XVI w. Natomiast symboliczne rozumienie perspektywy jako poglądu/ obrazu mentalnego jest datowane na drugą połowę XVIII w (Chambers Dictionary of Etymology 2006).

* Zakład Językoznawstwa Angielskiego i Ogólnego, Instytut Anglistyki, Wydział Filologiczny, Uniwersytet Łódzki, ul. Pomorska 171/173, 90-236 Łódź. 
Perspektywa jest niewątpliwie ważnym aspektem komunikacji. Jako nadawcy i odbiorcy komunikatów, formułujemy je oraz interpretujemy zawsze z pewnej perspektywy, na którą mają wpływ czynniki zewnętrzne i wewnętrzne. Językoznawcy kognitywni wymieniają wśród nich m.in. przeszłość, różne przeżycia, doświadczenia fizyczne i kulturowe. Według Langackera (1999: 203), nasza (mentalna) percepcja świata wynika z wcześniejszych doświadczeń i jest w jakimś stopniu stronnicza (ang. biased), ponieważ nie istnieje neutralny, wszystkowiedzący czy niezaangażowany obserwator. Dlatego Lakoff i Johnson (1988: 187) oznajmili: „Nie wierzymy, że istnieje coś takiego jak obiektywna (absolutna i bezwarunkowa) prawda [...] Wierzymy, że istnieją prawdy".

Złożoność terminu i pojęcia perspektywa wynika z jego historii i wcześniejszych zastosowań w różnych dziedzinach, dlatego warto pokrótce przedstawić, jak kształtowało się jego rozumienie. Według Becocciego-Frienze (1998: 232) perspektywa, rozumiana pierwotnie jako zjawisko optyczne, pojawiła się po raz pierwszy w starożytnych naukach ścisłych - opisana przez Euklidesa w dziele Optica ok. 300 r. p.n.e. Nieco później, w 25 r. p.n.e, rzymski architekt Witruwiusz zastosował grecką i rzymską teorię ,znikającego punktu” do architektury i opisał perspektywę jako metodę szkicowania. Ptolemeusz używał znanych mu teorii optycznej geometrii i perspektywy linearnej do rysowania map (1998: 232). Z początkiem Renesansu, pojęcie perspektywy upowszechniło się w sztuce, gdy XV-wieczny włoski architekt i rzeźbiarz Filippo Brunelleschi zastosował perspektywę linearną w malarstwie. Również inni twórcy renesansowi (Masaccio, Masolino, Donatello), zainspirowani odkryciami Brunelleschiego, próbowali w tej sposób oddać głębię obrazu (1998: 220). Perspektywa malarska ewoluowała z czasem od jednopunktowej/centralnej (np. Święta Trójca Masacciego) do dwupunktowej wprowadzonej przez Canaletta, Poussina i Piranessiego w XVIII w. (Tyler 2000: 492-497). Zastosowanie perspektywy powietrznej pozwoliło na jeszcze pełniejsze oddanie głębi obrazu. Dobrym przykładem połączenia perspektywy linearnej i powietrznej jest XIX-wieczny obraz Williama Turnera Wenecja (Burnet 2008: 26). W przeciwieństwie do swych poprzedników, twórcy kolejnego stulecia - kubiści, futuryści, abstrakcjoniści - porzucili próby wiernego odtworzenia trójwymiaru i ,spłaszczyli” swoje obrazy. Kubiści próbowali jednak oddać holistycznie doświadczenie wizualne stosując wielowymiarowość, aby skompilować różne punkty fizycznego postrzegania przedmiotu (Humphreys 1992: 270). W efekcie ich obrazy zdają się przedstawiać dany przedmiot/sytuację z różnych punktów widzenia/punktów obserwacji (np. Skrzypce i dzban Georgesa Braque’a). Jednym z najciekawszych twórców eksperymentujących z perspektywą był Mauritius Escher, którego Relatywność (1953) przedstawia przestrzeń złożoną z trzech różnych planów, każdy obserwowany z innego punktu.

Pojęcie perspektywy, rozumianej już w sposób bardziej figuratywny, pojawia się też wkrótce w teorii literatury. Oprócz lub zamiast tego terminu używa się tu wyrażenia punkt widzenia. Routledge Encyclopedia of Narrative 
Theory (2010: 442) definiuje ten termin jako psychologiczną i ideologiczną pozycję, z której są przedstawiane dane sytuacje; perspektywę, przez którą są filtrowane wydarzenia. Historia perspektywy literackiej jest kwestią złożoną, lecz warto zauważyć, że jest ona najczęściej związana z opowieścią i jej (jedynym lub więcej niż jednym) narratorem. Podobnie jak perspektywa malarska, narracja ewoluowała i stawała się coraz bardziej „dojrzała”. Za ważną jej strategię może zostać uznana fokalizacja (przyjęcie wewnętrznej lub zewnętrznej perspektywy, z której prezentowana jest narracja), rozwinięta przez Henry'ego Jamesa, a następnie przekształcona przez Jamesa Joyce'a i Virginię Woolf w technikę strumienia świadomości. Innymi ciekawymi strategiami narracyjnymi są polifonia lub heteroglosja, opisywane przez Michaiła Bachtina (Routledge Encyclopedia of Narrative Theory 2010: 390). Kategoria punktu widzenia może być także relewantna w poezji - kiedy odnosi się do punktu obserwacji osoby mówiącej oraz (do pewnego stopnia) w dramacie - gdzie jest widoczna na poziomie interakcji między dramatis personae (McIntyre 2004: 156). Pojęcie to w kontekście analizy literackiej ma już dłuższą tradycję; omawiał je np. w swej monografii Boris Uspensky (1973), a jeszcze wcześniej Bachtin (1934).

W swoich rozważaniach chciałabym jednak skupić się na kwestii perspektywy i punktu widzenia w świetle nieco późniejszej teorii kognitywnej, reprezentowanej tu głównie przez Ronalda Langackera (1987), by spróbować sprawdzić, czy takie podejście wnosi coś nowego do rozumienia tych pojęć i ich użycia w analizie tekstu. Teoria kognitywna wydaje się spójna i wyjaśnia wiele kwestii związanych z mentalnymi podstawami języka. W jej ramach perspektywa uważana jest za jedną z najważniejszych i najbardziej oczywistych operacji konstruowania mentalnego sceny (,the most obvious [...] of the construal operations", zob. Croft, Cruse 2004: 58), czyli narzędzi obrazowania (ang. imagery).

\section{Obrazowanie wg Langackera}

Według teorii językoznawstwa kognitywnego, każda sytuacja może być mentalnie konstruowana lub obrazowana na rożne sposoby (Langacker 1995: 19). Langacker (1995: 166) twierdzi, że znaczenie danego wyrażenia ,jest funkcją [...] treści pojęciowej i nałożonego na nią obrazu", czyli nie jest determinowane przez obiektywną rzeczywistość, a raczej jest pochodną zbudowanej przez nas kognitywnej reprezentacji danej sytuacji.

Wśród wymiarów obrazowania/konstruowania sceny (ang. imagery/scene construal) Langacker (2008: 85) wymienia poziom uszczegótowienia/schematyczności (ang. level of specificity/schematicity), ogniskowanie (focusing), wyróżnienie (profiling) oraz perspektywę. Pierwszy z nich odnosi się do decyzji o tym, jak szczegółowo (czy też z jaką ziarnistością/rozdzielczościa) przedstawimy sobie mentalnie - a w konsekwencji wyrazimy językowo - daną scenę lub relację 
(por. „ciotka” vs. „krewna”, gdzie pierwsze pojęcie jest bardziej szczegółowe, a drugie bardziej schematyczne). Każde pojęcie może zostać doprecyzowane lub skonkretyzowane poprzez uszczegółowienie jego atrybutów (2008:. 86).

Ogniskowanie jest definiowane jako „wybór treści pojęciowej dla celów prezentacji językowej oraz konfiguracja tej treści, którą można metaforycznie opisać jako podział na plan pierwszy i tło" (2008: 88). O takim podziale możemy mówić np. wtedy, gdy używamy utrwalonego doświadczenia w celu interpretacji nowego doświadczenia (2008: 89). Układ figura - tło był wcześniej opisywany przez badaczy percepcji wzrokowej. Langacker (1987) traktuje ten aspekt obrazowania jako jedną z części składowych perspektywy, dlatego powrócę do niego w dalszej części tej sekcji.

Kolejnym wymiarem obrazowania jest wyróżnienie, o którym Langacker (2008: 100) pisze w sposób następujący: „wszystko, co zostaje wybrane, jest wyróżnione w stosunku do tego, co selekcji nie podlega, a plan pierwszy jest ważniejszy niż tło". W ramach tego pojęcia możemy mówić o profilowaniu, definiowanym jako uwypuklenie danego elementu w obrębie bazy, tak, aby zyskał on szczególny stopień wyróżnienia, oraz o układzie trajektor/landmark, czyli o opozycji 'figury prymarnej' i 'figury sekundarnej' w profilowanej relacji (Langacker 1995: 165, 169).

Perspektywa jest przedstawiona jako czwarty wymiar obrazowania, który ma dalsze składowe. Langacker nie jest tu konsekwentny, wymieniając w publikacjach z różnych lat odmienne substruktury perspektywy:

- (Langacker 1987): układ figura - tło (figure-ground distinction), punkt widzenia (viewpoint), deiksa (deixis), konceptualizacja podmiotowa lub przedmiotowa (subjective/objective conceptualization);

- (Langacker 1991; 1995): punkt obserwacji (vantage point), orientacja (orientation), konceptualizacja podmiotowa lub przedmiotowa (subjective/objective conceptualization);

- (Langacker 1999): punkt obserwacji (vantage point)/punkt widzenia (viewpoint), punkt odniesienia (reference point), skanowanie wizualne (visual scanning);

- (Langacker 2008): punkt obserwacji (vantage point), konceptualizacja przedmiotowa i podmiotowa (subjectivity/objectivity distinction), dynamiczność (dynamicity).

Niespójność ta sugeruje, że decyzja o przyjęciu danej perspektywy zależy od wielu zazębiających się czynników. Według Langackera (1987), sformułowanie jednej definicji tej operacji pojęciowej nie jest łatwym zadaniem, jednak poprzez analizę jej substruktur oraz związanych z nimi zagadnień można wypracować pewne ramy teoretyczne.

Poniżej omówię bardziej szczegółowo zestaw substruktur perspektywy, zaproponowany przez Langackera w 1987 r., który jako najbardziej spójny wykorzystam w późniejszej analizie tekstów. 


\section{Perspektywa wg Langackera}

\subsection{Układ figura - tło}

Pierwszą z omówionych przez Langackera substruktur perspektywy jest uktad figura - tło. Dany element sceny może być postrzegany jako figura, jeśli jest uwypuklony, stanowi najbardziej wyrazisty element (Langacker 1987: 120, Evans 2007: 32). Figura jest wyraźnie widoczna w zestawieniu z pozostałymi elementami sceny, stanowiącymi jej tło. W przypadku postrzegania wzrokowego, to naturalne prawa percepcji wyznaczają, które elementy przyciągną uwagę, a więc będą odbierane jako figura: są to przede wszystkim obiekty małe, jasne, poruszające się lub potencjalnie ruchome, które kontrastują z większym, ciemniejszym tłem, np. biała kropka na czarnej ścianie. Podobne prawa mogą także obowiązywać w domenie słuchowej - por. dźwięk na tle ciszy (Langacker 1987: 120-122). Układ figura - tło, szczególnie w przypadku operacji mentalnych, nie jest jednak ściśle zdeterminowany; każdy obserwator może w dowolny sposób interpretować daną scenę i przydzielić role figury i tha innym jej elementom, uznając je za ważne na podstawie np. swych wcześniejszych doświadczeń, posiadanej wiedzy, aktualnego kontekstu.

Rozróżnienie między figurą a tłem, podobnie jak inne pojęcia bazujące na podobieństwie między organizacją percepcji a organizacją języka, zostało zapożyczone przez kognitywistów z psychologii postaci (Gestalt) - kierunku w psychologii pierwszych dekad XX w., badającego prawa percepcji wizualnej. Zostało ono opisane w 1915 r. przez duńskiego psychologa Edgara Rubina, który zwizualizował tę opozycję obrazkiem przedstawiającym wazon lub dwie twarze - interpretacja zależy od wyróżnienia przez obserwatora figury oraz tła (Graham 2008: 1).

\subsection{Punkt widzenia}

Według Langackera (1987), inną substrukturą perspektywy jest viewpoint. Langacker używa tego terminu zamiast wcześniej stosowanego point of view, chcąc prawdopodobnie uniknąć części skojarzeń, wiążących się z tym drugim terminem, funkcjonującym od dawna w literaturoznawstwie. W języku polskim obydwa terminy są jednak tłumaczone jako punkt widzenia.

Pojęcie to jest istotnym elementem w układzie oglądu. Można je zdefiniować najogólniej jako „miejsce zajmowane w określonym momencie przez nadawcę lub odbiorcę" (Langacker 2008: 110). Ta sama sytuacja może być postrzegana i opisywana z różnych punktów widzenia, czego następstwem jest powstanie różnych jej obrazów (2008: 110). Nadawca może przyjąć (mentalny) punkt widzenia, który nie będzie tożsamy z jego faktycznym umiejscowieniem lub może opisać sytuację z punktu widzenia innej osoby (2008: 112). 
Na punkt widzenia składają się orientacja oraz punkt obserwacji (vantage point) (Langacker 1987: 122-123). Drugi z wymienionych elementów to fizyczna (lub wyobrażona) pozycja obserwatora, która pozwala mu na przyjmowanie różnych orientacji w stosunku do danej sceny (1987: 122-123). Orientacja została zdefiniowana przez Langackera jako pozycja względem osi pola widzenia obserwatora - daną scenę będziemy postrzegali inaczej w pozycji kanonicznej, a inaczej stojąc na głowie (1987: 123-124).

Wybór określonego punktu obserwacji wpłynie na wybór pierwszego oraz drugiego planu sceny (foreground/background alignment). Jednak należy zaznaczyć, że podział ten nie jest tożsamy z układem figura-tło, ponieważ obserwator może skupić swoją uwagę na obiekcie znajdującym się na drugim planie i uczynić z niego figurę (1987: 124).

\subsection{Deiksa (deixis)}

Według Langackera (1987: 126) wyrażenia deiktyczne zawierają odniesienia do tła kotwiczącego (wypowiedzi, jej uczestników lub miejsca) w swoim zakresie predykacji. Ich interpretacja zależy od kontekstu sytuacyjnego (Tabakowska 2001: 23). Możemy wyróżnić kilka rodzajów wyrażeń deiktycznych, np. odnoszących się do uczestników aktu mowy (zaimki osobowe) lub miejsca i czasu wypowiedzi (przysłówki). Wyrażenia określoności (predications of definiteness), takie jak przedimki lub określniki identyfikują opisywany przedmiot oraz odzwierciedlają jego odległość od obserwatora np. „this broken pencil” (Langacker 1987: 126-127). Podobną rolę mogą spełniać czasowniki odmieniane ( finite verbs), zdradzające czas wypowiedzi, wyrażenia presuponujące punkt odniesienia, np. czasowniki come i go, oraz w niektórych kontekstach przyimki (Langacker podaje za przykład over i across) (1987: 126-127).

Croft i Cruise (2004: 60) dodają, że elementy deiktyczne mogą działać na dwóch poziomach konceptualizacji - tożsamej z sytuacją aktu mowy lub przemieszczającej uczestników oraz czas wypowiedzi do innej przestrzeni. Używanie w narracji czasu teraźniejszego do opisania zdarzeń przeszłych (ang. narrative present) przybliża mentalnie odbiorcę do opowiadanego zdarzenia (2004: 60).

Na formę wypowiedzi mają także wpływ czynniki pozajęzykowe, takie jak wspólna płaszczyzna (ang. common ground) - podzielana przez interlokutorów wiedza, przekonania i postawy (2004: 60). Zjawisko to, nazywane przez Langackera (1987: 127) kotwiczeniem epistemicznym (ang. epistemic grounding), ma charakter deiktyczny i wpływa na treść i sposób wypowiedzi oraz łączy osobę mówiącą i słuchacza perspektywą epistemiczną, widoczną np. w użyciu rodzajników określonych i nieokreślonych (Croft, Cruise 2004: 60). 


\subsection{Konceptualizacja przedmiotowa i podmiotowa (= subiektywność, obiektywność)}

Różnica między konceptualizacją subiektywna a obiektywna zasadza się na stopniu obecności obserwatora w obrazowanej scenie. Langacker (2005: 25) wskazuje na ,asymetrię między obserwatorem a postrzeganym bytem w sytuacji postrzegania”. Maksymalna asymetria cechuje optymalny układ oglądu, w którym spełnione są następujące warunki: obserwator i byt postrzegany są całkowicie odrębni, przedmiot obserwacji znajduje się blisko obserwatora, ale go nie zawiera, obserwator skupia całą uwagę na postrzeganym bycie (Langacker 1987: 129). Gdy warunki te zostaną spełnione, można mówić o maksymalnej subiektywności podmiotu i maksymalnej obiektywności przedmiotu (Langacker 2008/2009: 113). Wraz ze zmniejszaniem się asymetrii między uczestnikami danej sceny maleje obiektywność bytu postrzeganego i subiektywność obserwatora. Najwyższy poziom obiektyfikacji obserwatora zostanie osiągnięty, gdy skieruje on uwagę na siebie, umieści się w centrum sceny, co odzwierciedla np. użycie zaimka osobowego „„” (lub w języku polskim - użycie czasownika w pierwszej osobie 1. poj.). Staje się wówczas zarówno konceptualizatorem, jak i obiektem konceptualizacji (Langacker 1987: 130-131). Można tu zauważyć, że Langacker używa terminów „obiektywny” i „subiektywny” w nieco odmienny sposób, niż zwykle je się stosuje.

Omówione aspekty perspektywy składają się na jej holistyczną definicję wg Langackera (1987). Jak już zostało wspomniane wyżej, o perspektywie możemy mówić zarówno w kontekście relacji przestrzennych, jak i bardziej abstrakcyjnych. W tym pierwszym przypadku, perspektywa obserwatora będzie zależeć w dużej mierze od jego relatywnej pozycji oraz punktu obserwacji; natomiast w domenach innych niż przestrzenne główną rolę będą spełniały wiedza, przekonania oraz poglądy (punkt widzenia).

\section{Perspektywa w konstrukcji i analizie tekstu literackiego}

W poniższej sekcji chciałabym przedstawić próbę zastosowania kognitywnego ujęcia perspektywy do analizy pięciu krótkich tekstów autorstwa Raymonda Queneau, wchodzących w skład jego Exercices de style [Ćwiczeń stylistycznych]. Zbiorek ten stanowi eksperyment literacki: 99 tekstów jest wariantami tej samej wyjściowej historii, którą opowiadają stosując różną perspektywę, punkt widzenia czy stylizację. Często zmianie podlega jedynie ich rejestr językowy lub konwencja graficzna; niektóre są pastiszami innych gatunków lub form literackich. Choć to również ciekawe formy, tutaj chciałabym przyjrzeć się tylko tekstom, egzemplifikującym umiejętność konceptualizowania sytuacji z różnych perspektyw. 
Rozważania bazują na tłumaczeniu Exercices de style przez Jana Gondowicza (2005). Choć forma polskiego tekstu może odbiegać od francuskiego oryginału, zachowuje on jego główną ideę i wywołuje zamierzony przez autora efekt. Punktem wyjścia dla kolejnych wariacji jest tekst Sprawozdawczo. Jak sugeruje tytuł, celem tego tekstu jest „obiektywne” przedstawienie wydarzeń, wprowadzenie czytelnika w zaistniałą sytuację. Narrator jest obecny w świecie przedstawionym (zdradza swoją obecność używając czasownika „spotykać” w pierwszej osobie liczby pojedynczej), jednak pozostaje ,,przezroczystym” obserwatorem postrzeganych wydarzeń. Według Langackera (2005: 26-27; 1987: 491), sytuacja, w której obserwator skupia całą swoją uwagę na postrzeganym obiekcie może być nazwana optymalnym układem oglądu - rola narratora jako obserwatora jest w nim zmaksymalizowana, podczas gdy jego rola jako obiektu obserwacji jest minimalna. Wrażenie „niewidzialności” narratora jest potęgowane brakiem przymiotników i przysłówków, które mogłyby wartościować zdarzenie bądź zdradzić jego stosunek emocjonalny do obserwowanej sytuacji. Dodatkowo efekt dystansu jest wzmocniony użyciem mowy niezależnej przytaczającej wypowiedź uczestnika wydarzenia („Powinieneś zafundować sobie przy płaszczu dodatkowy guzik”), dzięki czemu narrator pozostaje poza zakresem predykacji. Wszystkie te zabiegi mają na celu przedstawienie zdarzenia widzianego oczami osoby w żaden sposób niezaangażowanej, przypadkowego przechodnia, który stał się jego świadkiem.

\section{"Sprawozdawczo"}

W esce, godzina szczytu. Typek na oko dwudziestosześcioletni, flaczasty kapelusz o wstążce zastąpionej tasiemką, szyja przydługa, jakby naciągnięta wzwyż. Ludzie wychodzą. Typ, o którym mowa, wścieka się na sąsiada. Zarzuca mu, że go potrąca, ilekroć ktoś przechodzi. Płaczliwy ton, który chce być przykry Widząc wolne miejsce, rzuca się do przodu. Dwie godziny później spotykam go na Cour de Rome, przed dworcem Saint-Lazare. Jest z kolegą, który mówi: „Powinieneś zafundować sobie przy płaszczu dodatkowy guzik". Pokazuje mu gdzie (przy wycięciu) i dlaczego.

Niektóre z „przeróbek” tego bazowego tekstu są oparte na przedstawieniu wydarzeń z innych punktów widzenia (viewpoints) bądź z różnych punktów obserwacji (vantage point), co wpływa oczywiście na wybory językowe osoby mówiącej oraz konstrukcję tych tekstów.

\section{„Pierwszoosobowo"}

Ubranka mogłem się dziś nie wstydzić. Zainaugurowałem nowy kapelusz, i to całkiem w dechę, a także prochowiec, w którym czułem się byczo. X, co napatoczył mi się przed dworcem Saint-Lazare, aż wyłaził ze skóry, żeby zepsuć mi frajdę, próbując udowodnić, że ciuch jest zbyt wycięty i nie obejdzie się bez doszycia nadliczbowego guzika. Bądź co bądź nie śmiał się czepiać przynajmniej dęciaka.

Tuż przedtem zmyło się zdrowo łeb jednemu żłobowi, który jawnie próbował dać mi się we znaki, ile razy ktoś się przepychał przy wejściu czy wyjściu. Rzecz rozegrała się w jednym z tych zakichanych chamobusów, co pękają od hołoty jak raz w porze, kiedy muszę z któregoś skorzystać. 
Tekst „Pierwszoosobowo” to opowieść aktywnego uczestnika wydarzeń (a więc różnego od narratora „Sprawozdawczo”) z jego punktu widzenia, która może zostać nazwana subiektywną w nie-langackerowskim znaczeniu tego słowa. Narrator zaznacza swoją obecność w zakresie predykacji przedstawiając swoje obserwacje, emocje i odczucia. Granica pomiędzy obserwatorem a obiektem obserwacji zostaje zatarta - on sam staje się przedmiotem obserwacji, dlatego możemy mówić o obiektywnym lub wręcz egocentrycznym układzie oglądu (Langacker 2005: 26-28). Przyjęta perspektywa znajduje odzwierciedlenie w wyborach leksykalnych osoby mówiącej: słownictwo jest oceniające i nacechowane emocjonalnie, dzięki czemu pozwala na autokreację i zdradza stosunek narratora do samego siebie. Demonstrując swoje poczucie wyższości nad pozostałymi pasażerami, narrator wzmacnia efekt wyrazistości swojej postaci (ang. prominence). Mnogość czasowników w formie pierwszoosobowej (co zostało jednoznacznie zaznaczone już w tytule) oraz częste formy zaimka $j a(m i)$, wraz z efektem wywołanym przez subiektywny dobór słownictwa, skupiają uwagę czytelnika na postaci narratora bardziej niż na samych wydarzeniach, dlatego możemy postrzegać osobę mówiącą jako figurę pierwszoplanową, a przedstawione wydarzenia jako tło w układzie figura - tło. Co więcej, odwrócenie kolejności zdarzeń - konwersacja o guziku jest wspomniana jako pierwsza i poświęca jej się więcej uwagi niż wydarzeniom w autobusie - dodatkowo personalizuje opowiadanie i pozwala rozpoznać hierarchię zdarzeń według narratora (przedstawia je ze swojego mentalnego punktu widzenia). Zastosowanie odwróconej kolejności nadaje wydarzeniu z guzikiem większą rangę i pozwala czytelnikowi na jego interpretację jako tego ważniejszego, bardziej wyrazistego. Dana sytuacja może także zostać rozważona w kategorii profilowania: wówczas narrator, będąc wyróżnionym elementem relacji (trajektorem), staje się ,prymarnym ogniskiem profilowanej relacji” (Langacker 2008: 105).

\footnotetext{
„Biernie”

Transportowany autobusem, podporządkowanym marszrucie od rogatki Champerret, znalazłem się zdany na natłok mnóstwa ludzi: młodych, starych, kobiet, wojskowych. Z biletem padłym już ofiarą kasownika ogarnięty zostałem pokusą, by się rozejrzeć. Nic ciekawego nie dawało się dostrzec. Obserwacja dobiegła końca, gdy moja uwaga doznała wzbudzenia na widok młodego człowieka, którego szyja uznana być musiała za nazbyt długą. Ocenie podległ też jego kapelusz, opasany plecionką zamiast wstążki. Ilekroć do grona podróżnych dołączany był ktoś nowy, inicjowana była kolejna przepychanka. Co do mnie, dotknięty byłem milczącym cierpieniem, lecz młody człowiek o długiej szyi okazał się mimo wszystko poddany chęci oskarżenia sąsiada. Co było doń kierowane, nie zostało przeze mnie usłyszane, lecz ich wrogie spojrzenia raz i drugi zostały skrzyżowane. A wtedy młody człowiek o długiej szyi tknięty został ideą pospiesznego zajęcia wolnego miejsca.

Wieziony na powrót do rogatki Champerret, mijany byłem na pozór przez dworzec Saint-Lazare. Tam zobaczeniu przeze mnie uległ mój facet, pochłonięty dysputą z kumplem. Jej losy okazały się zawisłe od wskazanego palcem guzika tuż ponad wycięciem płaszcza. Potem uwieziony zostałem przez autobus, więc obaj nie mogli już być przeze mnie widziani. Zdany na pozycję siedzącą, pozbawiony byłem możności myślenia o czymkolwiek.
} 
Powyższa opowieść została przedstawiona z punktu obserwacji pasażera, który stał się świadkiem sceny w autobusie. Uwagę obserwatora zwrócił wysoki mężczyzna, który może być postrzegany jako figura w opozycji do tła - otoczenia, w którym „nic ciekawego nie dało się dostrzec”. Mężczyzna stał się podmiotem obserwacji, ponieważ według narratora wyróżniał się z thumu osobliwym wyglądem - nieproporcjonalnie długą szyją oraz kapeluszem, „opasanym plecionką”. Dalszą wyrazistość zapewnił sobie poprzez scenę kłótni z innym współpasażerem spowodowanej szturchnięciami i przepychankami w zatłoczonym autobusie; obserwator mógł poczuć do niego empatię, ponieważ sam również ich doświadczał (,dotknięty byłem milczącym cierpieniem”). W rezultacie utrwalił sobie w pamięci obraz mężczyzny na tyle dokładny, żeby po jakimiś czasie znów go rozpoznać, co znalazło wyraz w konstrukcji dzierżawczej „mój facet”, implikującej zatrzymanie tej postaci w jednej z przestrzeni mentalnych narratora. Jednak, jak się okazuje w podsumowaniu opowieści, młody człowiek zapewne nie pozostał tam długo gdy „uwieziony” przez autobus narrator stracił scenę z pola widzenia, pozbawiło go to „możności myślenia o czymkolwiek”. Operacje mentalne są tu więc wyraźnie zależne od percepcji wzrokowej. Zdanie: „co było doń kierowanie, nie zostało przeze mnie usłyszane" implikuje, że w scenie autobusowej narrator nie znajdował się wystarczająco blisko, aby usłyszeć rozmowę; odległość pozwoliła mu jedynie na obserwację zdarzenia. Podobnie, mógł zobaczyć „scenę guzikową”, ale również nie był w stanie usłyszeć rozmowy mężczyzn. Zakres jego postrzegania był warunkowany jego orientacją oraz punktem obserwacji, w tym przypadku czynnikami zewnętrznymi, niezależnymi od jego woli. Chociaż opowiadanie jest przedstawione z perspektywy obserwatora (perceiver/experiencer), w relacji do uczestników wydarzeń jest on tylko przypadkowym nieznajomym.

\section{„Odsiebnie"}

Już ja wiem swoje: taki typ, co się zaweźmie deptać wam po kulasach, może wnerwić. Ale dość stanąć okoniem, a przycupnie - tego już ja nie kapuję! - jak trusia. Już ja to raz widziałem na tylnej platformie autobusu S. Już ja umiałem ocenić jako ciut przydługą szyję tego młodzika, a ten niby opłot naokoło jego kapelusza tak samo za nieźle draczny. Już ja bym nigdy nie śmiał paradować w czymś takim na głowie. Ale już ja wam powiem: ten typ, ledwo napyskował innemu pasażerowi, co mu deptał po nogach, wziął, cupnął i kropka. Już ja dałbym mu w papę, takiemu śmierdzielowi, co by mi deptał po nogach.

W życiu bywa różnie, już ja wam powiem, i nie tylko góra z górą się zejdzie. Dwie godziny później, a już ja znów go widzę, tego chłopinę. Już ja go przyuważyłem przed dworcem Saint-Lazare. Już ja dobrze mu się przyjrzałem obok kumpla z tej samej gliny, jak ten mu mówił, już ja słyszę te rzeczy: „Ten guzik byś lepiej podniósł”. Już ja mam oko: pokazał najwyższy guzik.

Powyższy tekst jest przykładem przybrania perspektywy egocentrycznej, bardzo naturalnej kiedy chcemy wyrazić swoją opinię. Jednak ekstremalne nagromadzenie elementów autoreferencyjnych (,już ja...”) sprawia 
wrażenie parodiowania tej tendencji. Stosując terminologię Langackera, narrator wyraziście zaznacza tu swoją obecność w zakresie predykacji. Deiktyczne określenia, idiolektyczne wybory leksykalne osoby mówiącej („stanąć okoniem”, ,jak trusia”, „napyskował” itp.) oraz wyrażenia o dużym ładunku emocjonalnym („deptać po kulasach”, „śmierdziel”, „nie kapuję!”, „dałbym mu w papę") wysoce personalizują tekst. Jest pewnym paradoksem, że tekst przyjmujący perspektywę egocentryczną implikuje obecność odbiorcy poprzez wtrącenia (,już ja wam powiem”), a tym samym przybiera konwencję stylu konwersacyjnego.

\section{„Teraz"}

W południe upał ściele się wokół stóp podróżujących autobusem. Aż osadzona na długiej szyi tępa głowa, zdobna groteskowym kapeluszem, osiąga samo zapłon: z miejsca bluzga pyskówką. Ażeby zresztą co rychlej struchleć w atmosferze zbyt gęstej na żwawe sączenie do ucha co najcięższych obelg. Idzie się więc siąść do środka, w chłodek. Później między Cour de Rome a Cour de Havre wyniknąć mogą kwestie odzieżowe w związku z jakimś guzikiem, który bez ceremonii miętoszą tłuste od potu palce.

Powyższa opowieść jest niezwykle interesująca pod względem relacji forma - treść. Wydarzenia opisane przez narratora znajdują się na drugim planie (background), uwaga odbiorcy ogniskuje się natomiast na formie ich przekazu. Metonimiczny opis skupia się na częściach ciała (stopy, szyja, głowa, uszy i palce), które zastępują ludzi - możemy więc mówić o relacji synekdochicznej. Kłótnia między mężczyznami jest również implikowana metonimicznie w zdaniu „sączenie do ucha co najcięższych obelg”, w którym ucho pełni rolę odbiorcy, natomiast czasownik sączyć wskazuje na nadawcę komunikatu. Użycie określenia „wyniknąć mogą kwestie odzieżowe” dalej pomniejsza rolę ludzi w całej sytuacji. Ponieważ nasza percepcja jest zorientowana antropocentrycznie, w tekście zauważamy brak osób: oprócz fragmentaryczności uczestników zdarzenia, również narrator wspomina o sobie bezosobowo („Idzie się więc siąść do środka, w chłodek"). Każdy z tych zabiegów przyczynia się do wrażenia, że opowieść jest „rozmyta”, pozbawiona wyraźnej akcji i osoby, która mogłaby zostać uznana za figurę pierwszoplanową. Choć wydaje się opowiedziana z punktu widzenia narratora, widać, że bagatelizuje on całe zajście, odbiera je jako niewartą szerszej uwagi drobnostkę. Być może winny tej obojętności jest obezwładniający upał, uniemożliwiający jasne myślenie.

\section{Wnioski}

Wybór perspektywy, jako jeden z najważniejszych aspektów obrazowania, jest zjawiskiem niezwykle ważnym w naszym myśleniu i zachowaniu językowym. Zwykle dokonujemy go intuicyjnie, nie zastanawiając się nad jego 
mechanizmem. W moim opracowaniu starałam się spojrzeć na tę operację mentalną oraz jej wpływ na formę językową nieco bardziej świadomym okiem językoznawcy o nachyleniu kognitywnym.

Zwrócenie uwagi na ten aspekt obrazowania w analizie tekstów literackich oferuje szersze możliwości ich interpretacji, czyni je bardziej transparentnymi. Widać to szczególnie podczas analizy tekstów, które miały na celu zabawę perspektywą i egzemplifikują bogactwo i kreatywny potencjał języka. Teksty Raymonda Queneau zawarte w zbiorze Ćwiczenia stylistyczne pokazują możliwości różnej konceptualizacji/obrazowania tej samej treści, a pojęcie perspektywy oraz jego składowe (punkt widzenia, konceptualizacja przedmiotowa i podmiotowa, układ figura - tło wraz z powiązanymi relacjami deiktycznymi) jest niewątpliwie przydatne zarówno w ich konstruowaniu, jak i opisie

Obranie danej perspektywy determinuje wybory leksykalne obserwatora sceny. Bezpośredni wpływ na formę ma punkt widzenia (zarówno fizyczny, jak i mentalny), który określa zakres predykacji i jest związany z takimi czynnikami wewnętrznymi jak zaangażowanie obserwatora, jego wiedza, przekonania oraz poglądy; wśród czynników zewnętrznych można wymienić fizyczne i temporalne usytuowanie obserwatora oraz kontekst sytuacji. Zmiana punktu widzenia dostarcza nowych informacji, a więc pozwala na poszerzenie wiedzy o danej sytuacji. Elementy deiktyczne wskazują odczucia, relacje i powiązania pomiędzy uczestnikami sceny oraz zdradzają lokację czasowo-przestrzenną wydarzenia. Są one także kluczem do interpretacji obecności konceptualizatora lub jej braku $\mathrm{w}$ zakresie predykacji danej sceny.

\section{Bibliografia}

Bachtin, M. [1934] 1981. "Discourse in the Novel”, [w:] M. Holquist (ed.), The Dialogic Imagination: Four Essays by Mikhail Bakhtin, Austin: University of Texas Press.

Becocci-Firenze. 1998. "Brunelleschi's peepshow \& the origins of perspective", [w:] P. A. Calter (ed.), Squaring the Circle: Geometry in Art and Architecture, New York: Wiley.

Burnet, J. 2008. A practical treatise on painting: in three parts: consisting of hints on composition, chiaroscuro, and colouring: the whole illustrated by examples from the Italian, Venetian, Flemish, and Dutch schools, London: Carpenter and Son.

Barnhart, R., S. Steinmetz (eds.). 2006. Chambers Dictionary of Etymology, New York: Chambers. Hasło: Perspective.

Croft, W., A. D. Cruse. 2004. Cognitive Linguistics, Cambridge: Cambridge University Press.

Evans, V. [2007] 2009. Leksykon językoznawstwa kognitywnego, Kraków: Universitas.

Graham, L. 2008. "Gestalt Theory in Interactive Media Design”, Journal of Humanities and Social Sciences 2(1).

Herman, D., J. Manfred (eds.). 2002. Routledge Encyclopedia of Narrative Theory, New York: Routledge. Haslo: Point of view.

Humphreys, G. 1992. Understanding Vision: An Interdisciplinary Perspective, Cambridge, Mass.: Blackwell. 
Lakoff, G., M. Johnson. [1980] 1988. Metafory w naszym życiu, tłum. T. P. Krzeszowski, Warszawa: PIW.

Langacker, R. 1987. Foundations of Cognitive Grammar, Vol. 1: Theoretical Prerequisites, Stanford, Cal.: Stanford University Press.

Langacker, R. 1991. Foundations of Cognitive Grammar, Vol. 2: Descriptive Applications, Stanford, Cal.: Stanford University Press.

Langacker, R. 1995. Wykłady z gramatyki kognitywnej. Kazimierz nad Wisła, grudzień 1993, red. H. Kardela, tłum. Zbiorowe, Lublin: Wydawnictwo UMCS.

Langacker, R. 1999. Grammar and Conceptualisation, Berlin: Mouton de Gruyter.

Langacker, R. 2005. Obserwacje i rozważania na temat zjawiska subiektyfikacji, tłum. M. Majewska, Kraków: Universitas.

Langacker, R. 2008. Cognitive Grammar: A Basic Introduction, Oxford: Oxford University Press. Langacker, R. [2008] 2009. Gramatyka kognitywna. Wprowadzenie, red. E. Tabakowska, M. Buchta, Kraków: Universitas.

McIntyre, D. 2004. "Point of View in Drama: A Socio-Pragmatic Analysis of Dennis Potter's Brimstone and Treacle", Language and Literature 13(2): 139-160.

Queneau, R. [1947] 2005. Ćwiczenia stylistyczne, tłum. J. Gondowicz, Izabelin: Czuły barbarzyńca.

Stownik języka polskiego, http://sjp.pwn.pl/szukaj/perspektywa, Hasło: Perspektywa [dostęp on-line 30.01.2014].

Sobol E. (red.). 2002. Stownik języka polskiego Warszawa: PWN. Hasło: Perspektywa.

Tabakowska, E. 2001. Gramatyka i obrazowanie. Wprowadzenie do językoznawstwa kognitywnego, Kraków: Wyd. Oddziału PAN.

Tyler, Ch. W. 2000. "Perspective as a geometric tool that launched the Renaissance", Human Vision and Electronic Imaging V (Proceedings of SPIE, Vol. 3959).

Uspensky, B. [1970] 1973. A Poetics of Composition: The Structure of the Artistic Text and Typology of a Compositional Form, transl. V. Zavarin, S. Wittig, Berkeley: University of California Press. 